\title{
Matlak (al-Mathâli') Teks, Konteks dan Penerapan
}

\author{
Ahmad Hariz bin Bely ${ }^{1 *}$, Mohd Jais Anuar Bin Ahmad ${ }^{2}$ \\ ${ }^{1,2}$ Universiti Sultan Zainal Abidin, 21300 Kuala Terengganu Malaysia \\ 1*Email: ahmadhariz007@gmail.com
}

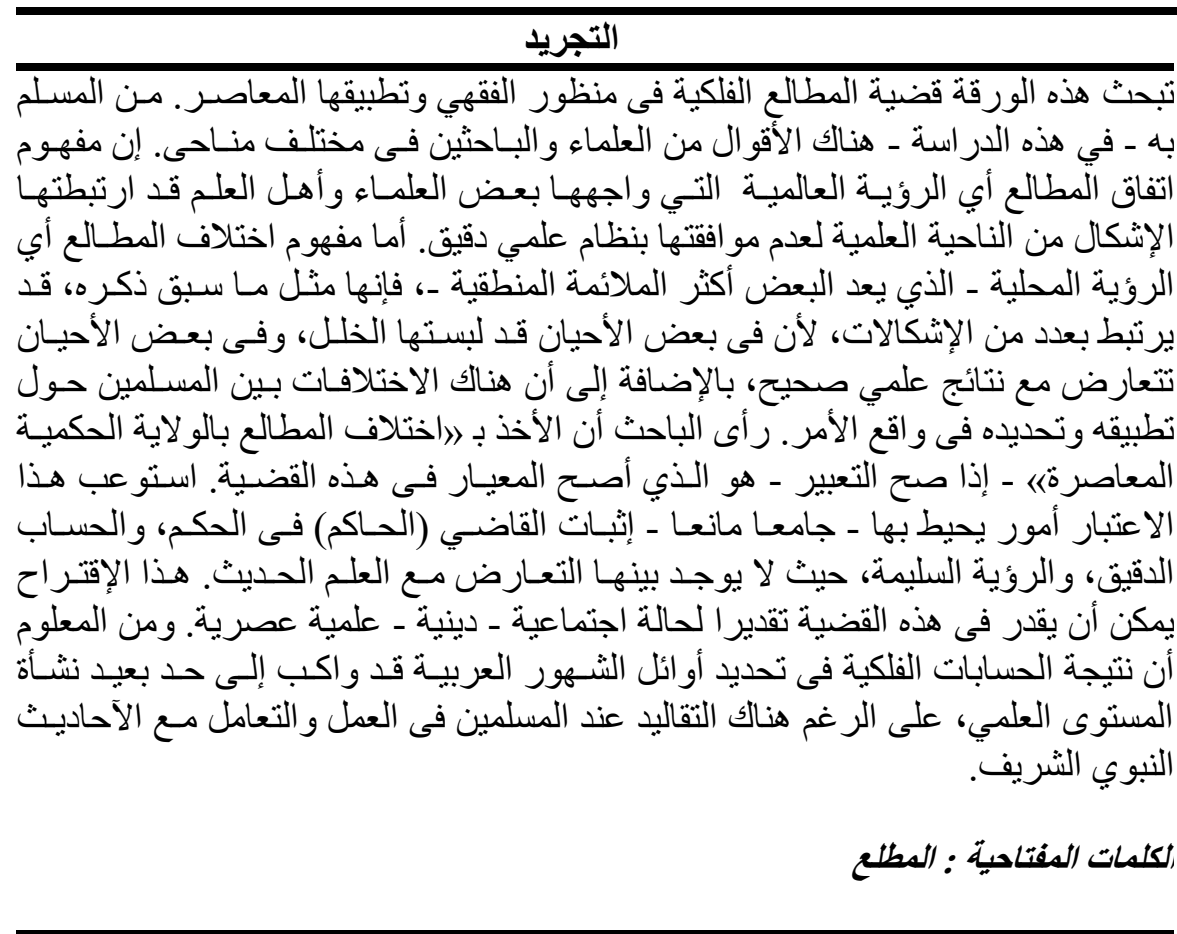

\begin{abstract}
Abstrak
Tulisan ini mengkaji tentang matlak dari sisi normatif dan konsep penerapannya dalam konteks modern. Diakui kajian tentang hal ini menuai respon dan pandangan yang beragam oleh para ulama dan peneliti dari berbagai kalangan. Konsep matlak global yang banyak ditawarkan para ulama klasik dan ulama kontemporer memiliki sisi kelemahan, yaitu dalam banyak kasus tidak bersesuaian dengan ilmu pengetahuan modern. Sementara konsep matlak lokal (rukyat lokal) yang dipandang lebih logis juga memiliki sisi problematis, karena rukyat an sich memiliki banyak kekurangan, disamping dalam teknis penerapan dan rumusannya juga masih menyisakan banyak perdebatan. Sejauh ini menurut penulis, 'matlak lokal wilayatul hukmi modern' yang secara aktif-kolektif mengakomodir peran negara, hisab rukyat dan sains modern layak diapresiasi karena dalam tataran praktisnya mengakomodir dua konsep matlak yang nampak berhadapan (matlak lokal dan matlak global). Konsep ini untuk sementara ditawarkan melihat konteks sosio religiusintelektual modern dimana hisab astronomis penentuan awal bulan terus menguat, disamping konteks realitas umat yang tidak dapat lepas dari keterikatannya dengan hadis-hadis Nabi Saw.
\end{abstract}

Artikel Info

Received:

26 April 2021

Revised:

05 Mei 2021

Accepted:

21 Mei 2021

Published:

08 Juni2020

\section{Kata Kunci : Matlak}




\section{AL-MARSHAD: JURNAL ASTRONOMI ISLAM DAN ILMU-ILMU BERKAITAN \\ ISSN 2442-5729 (print) || ISSN 2598-2559 (online) \\ http://jurnal.umsu.ac.id/index.php/almarshad \\ DOI: //doi.org/10.30596/jam.v7i1.6861 | Vol. 7, No. 1Juni 2021}

\section{A. Pendahuluan}

Matlak berasal dari bahasa Arab yaitu al-mathla' atau al-mathâli' yang bermakna tempat terbit atau tempat muncul. ${ }^{1}$ Matlak adalah tempat terbit matahari, terbit bulan atau terbit fajar. Matlak dimaksud disini adalah batas geografis keberlakuan rukyat. $^{2}$ Terminologi matlak muncul sebagai akibat proses astronomis siklus bulan mengelilingi bumi. Berbedanya waktu terbenam matahari (ikhtilâf al-maghârib) di suatu tempat disebabkan berbedanya waktu terbit matahari (ikhtilâf al-mathâli'), demikian juga dengan fajar. Secara umum matlak terbagi dua, yaitu matlak ikhtilâf (matlak lokal) dan matlak ittihâd (matlak global). Pengertian matlak ikhtilâf adalah penampakan hilal (baik dengan hisab maupun dengan rukyat) yang hanya berlaku di satu kawasan tertentu saja. Matlak ikhtilâf disebut juga matlak lokal. Adapun matlak ittihâd adalah penampakan hilal di satu kawasan tertentu dan berlaku pada semua kawasan dipermukaan bumi. Matlak ittihâd disebut juga dengan matlak global.

Secara astronomis perbedaan matlak disebabkan perbedaan lintang dan bujur suatu wilayah. Lintang ('ardh al-balad)

${ }^{1}$ Zain ad-Din Muhammad bin Abi Bakr arRazi, Mukhtar Ash-Shihhah (Kairo: Dar as-Salam, cet. I, 2007).

2 Susiknan Azhari, Ilmu Falak Perjumpaan Khazanah Islam Dan Sains Modern (Yogyakarta: Suara Muhammadiyah, cet. II, 2007). adalah jarak sepanjang meridian bumi diukur dari ekuator bumi (katulistiwa) sampai suatu tempat yang bersangkutan. Harga lintang tempat $0^{\circ}$ sampai $90^{\circ}$. Lintang tempat bagi tempat-tempat yang berada di belahan bumi utara disebut Lintang Utara (LU) diberi tanda positif (+) dan tempat-tempat yang berada di belahan bumi selatan disebut Lintang Selatan (LS) diberi tanda negatif (-). Lintang tempat dalam bahasa Inggris disebut latitude, dan dalam bahasa Arab disebut 'ardh al-balad dan biasanya digunakan lambang $\varphi$ (phi). Mengetahui lintang dan bujur tempat merupakan dasar perhitungan kiblat, waktu shalat, awal bulan, dan gerhana. ${ }^{3}$

Adapun bujur (thûl al-balad) adalah jarak sepanjang ekuator bumi dihitung dari meridian yang melewati kota Greenwich sampai meridian yang melewati tempat bersangkutan. Harga bujur tempat mulai $0^{\circ}$ sampai $180^{\circ}$. Bagi tempat-tempat yang berada disebelah barat Greenwich disebut Bujur Barat (BB) dan diberi tanda negatif (). Bagi tempat-tempat yang berada disebelah timur Greenwich disebut Bujur Timur (BT) dan diberi tanda positif (+). Dalam bahasa Inggris disebut longitude, dan dalam bahasa Arab disebut thûl al-balad dan biasanya digunakan lambang $\lambda$ (lamda). Mengetahui

${ }^{3}$ Susiknan Azhari, Ensiklopedi Hisab Rukyat (Yogyakarta: Pustaka Pelajar, 2005). 


\section{AL-MARSHAD: JURNAL ASTRONOMI ISLAM DAN ILMU-ILMU BERKAITAN \\ ISSN 2442-5729 (print) || ISSN 2598-2559 (online) \\ http://jurnal.umsu.ac.id/index.php/almarshad \\ DOI: //doi.org/10.30596/jam.v7i1.6861 | Vol. 7, No. 1Juni 2021}

lintang dan bujur tempat juga merupakan dasar perhitungan kiblat, waktu salat, awal bulan, dan gerhana. ${ }^{4}$ Aapabila nilai bujur dua wilayah sama maka memungkinkan penampakan hilal di dua wilayah akan sama meskipun lintangnya berbeda, namun apabila dua wilayah itu bujurnya berbeda maka penampakan hilal tidak sama.

Diskursus matlak muncul ke permukaan sejak munculnya hadis Kuraib, yaitu diskusi yang terjadi antara Kuraib dan Ibn Abbas. Kuraib menjelaskan, pada menjelang bulan Ramadhan, Muawiyah dan penduduk Syam telah melihat hilal, namun Ibn Abbas dan penduduk Madinah belum melihat hilal. Dalam faktanya Ibn Abbas tidak menggunakan laporan penduduk Syam yang telah melihat hilal. Peristiwa ini dianggap sebagai latar belakang munculnya terminologi matlak.

Ittihâd \& ikhtilâf matlak merupakan istilah fikih bernuansa astronomi yang muncul sesudah masa Nabi Saw. Istilah ini muncul seiring berbedanya waktu dan tempat terjadinya rukyat dan banyaknya laporan terlihat hilal dari berbagai tempat dimana ketika itu tidak tersedia sarana penyebaran informasi yang memadai. Ketika Nabi Saw berada bersama kaum muslimin di kota mulia Mekah dan kota bersinar Madinah, penetapan awal puasa dan hari

\footnotetext{
${ }^{4}$ Susiknan Azhari, Ensiklopedi Hisab Rukyat.
}

raya selalu disandarkan kepada beliau tanpa informasi yang lain, dan informasi dari Nabi Saw ini berlaku dan disampaikan kepada seluruh kaum muslimin (matlak global). Setelah Nabi Saw wafat, ekspansi wilayah Islam terus dilakukan oleh para sahabat. Dari sini mulai muncul perbedaan dikalangan para sahabat \& umat dalam menafsirkan hadis-hadis Nabi Saw, sebagian berpegang pada zahir nas, yang lain berpegang pada konteks nas. Dalam faktanya lagi, mulai banyak orang yang mengaku melihat dan melaporkan hilal, padahal kualitas kesaksian dan laporannya masih diragukan, dan ketika itu sarana informasi hilal dari satu tempat ke tempat lain sangat lamban. Dari sini akhirnya muncul diskursus matlak lokal.

Pada kenyataannya lagi, ilmu pengetahuan memberi pengaruh signifikan terhadap persoalan ini. Dari sini para ulama berijtihad bahwa perbedaan matlak akan berpengaruh pada perbedaan memulai puasa dan hari raya (matlak lokal). Dalam konteks modern, persoalan matlak masuk dalam ranah fikih, sains dan siyâsah syar'iyyah.

\section{B. Metode Penelitian}

Penelitian ini menggunakan metode deskriptif kualitatif, dan termasuk dalam jenis penelitian kepustakaan. Kemudian pengumpulan data menggunakan teknik studi pustaka dan literatur. Sumber data yang 


\section{AL-MARSHAD: JURNAL ASTRONOMI ISLAM DAN ILMU-ILMU BERKAITAN \\ ISSN 2442-5729 (print) || ISSN 2598-2559 (online) \\ http://jurnal.umsu.ac.id/index.php/almarshad \\ DOI: //doi.org/10.30596/jam.v7i1.6861 | Vol. 7, No. 1Juni 2021}

dimaksud adalahbuku-buku, jurnal atau artikel ilmiah yang memiliki tema terkait dengan pembahasan matlak. Studi kepustakaan ini bertujuan untuk mengkaji lebih dalam tentang matlak dari sisi normatif dan konsep penerapannya dalam konteks modern dari berbagai pandangan yang beragam oleh para ulama dan peneliti dari berbagai kalangan.

\section{Hasil dan Pembahasan}

Terdapat dua pendapat tentang ikhtilâf dan ittihâd matlak dikalangan fukaha:

1.) Tidak berlaku ikhtilâf matlak (lâ 'ibrah bi ikhtilâf al-mathâli')

Kelompok ini menyatakan tidak berlaku ikhtilâf matlak dalam penetapan kemunculan hilal untuk menentukan awal puasa dan hari raya. Kelompok ini menyatakan apabila hilal terbukti (tsabat) terlihat di suatu negeri maka berlaku bagi semua penjuru bumi. Pendapat ini dipedomani oleh Hanafiyah, Malikiyah, satu pendapat dalam mazhab Syafi'i, dan Hanabilah.

Dalil yang digunakan dalam kelompok ini adalah:

1. Firman Allah Swt QS. Al-Baqarah [02] ayat 184: "faman syahida minkum asy-syahr fa al-yashumhu" (maka siapa diantara kamu yang telah menyaksikan bulan maka hendaklah ia berpuasa).

2. Hadis-hadis Nabi Saw tentang memulai puasa dan hari raya bersifat umum sehingga berlaku global tanpa membatasi wilayah keberlakuan.

3. Berdasarkan para saksi yang adil dan terpercaya yang menyatakan bahwa hari itu adalah bulan Ramadhan, sehingga kaum muslimin wajib berpuasa berdasarkan kesaksian itu dimana saja.

4. Alasan logika, dengan penyeragaman berpotensi menyatukan umat Islam di berbagai penjuru.

Mazhab Maliki menyatakan bila hilal telah terlihat di suatu daerah berdasarkan kesaksian dua orang atau lebih, maka kesaksian ini berlaku untuk seluruh negeri baik jauh maupun dekat. Malikiyah sama sekali tidak mentolerir jarak qashr salat atau penyeragaman (ittifâq) matlak. ${ }^{5}$ Pendapat senada juga dikemukakan oleh Hanafiyah dan Hanabilah, namun Hanafiyah menambahkan bahwa kesaksian harus dipersaksikan dihadapan $q \hat{a} d h \hat{l}^{6}$

Al-Qarafi (w. $684 \mathrm{H}$ ), seorang ulama Malikiyah, dalam karyanya "adz-

5 Wahbah az Zuhaili, Al-Fiqh Al-Islâmî Wa Adillatuh (Beirut: Dar al Fikr).

6 'Abd ar-Rahmân al-Jazîrî, Kitâb Al-Fiqh 'Alâ Al-Madzâhib Al-Arba'Ah (Kairo: Mu'assasah alMukhtâr, cet. I, 2001). 


\section{AL-MARSHAD: JURNAL ASTRONOMI ISLAM DAN ILMU-ILMU BERKAITAN \\ ISSN 2442-5729 (print) || ISSN 2598-2559 (online) \\ http://jurnal.umsu.ac.id/index.php/almarshad \\ DOI: //doi.org/10.30596/jam.v7i1.6861 | Vol. 7, No. 1Juni 2021}

Dzakhî'rah" menyatakan bahwa terlihatnya hilal di suatu negeri menjadi sebab wajibnya puasa bagi seluruh negeri. ${ }^{7}$ Pendapat ini berdasarkan keumuman hadis Nabi Saw "puasalah kamu karena melihat hilal dan berbukalah karena melihat hilal, jika hilal tertutup oleh awan maka sempurnakanlah bilangan Sya'ban menjadi 30 hari" [HR. alBukhari \& Muslim].

Wajh ad-dilâlah dalil ini adalah bahwa Nabi Saw mengaitkan perintah puasa dengan pernyataan mutlak rukyat (li ru'yatihi). Rukyat yang terjadi di satu negeri atau di negeri lainnya, kedua-duanya disebut rukyat. Dengan demikian hukum rukyat itu berlaku umum dimana saja, kewajiban itu juga bersifat umum, hukumnya juga umum (menyeluruh) bagi semua wilayah (penjuru bumi) ${ }^{8}$

Ulama salaf Abdul Aziz bin Abdillah bin Abdirrahman bin Baz menyatakan berlakunya ittihâd matlak (matlak global) yaitu apabila hilal terlihat di satu wilayah maka rukyat tersebut berlaku bagi semua kawasan (negara) lain selama informasi itu sampai. Pendapat bin Baz ini didasarkan pada keumuman hadis-hadis terkait.

${ }^{7}$ Ahmad bin Idris al-Qarafi, Adz-Dzakhirah, $j$. 2, Tahkik: Al-Ustadz Sai'd Al-A'rab (Beirut: Dar alGharb al-Islami, cet. I, 1994).

${ }^{8}$ Muhammad Sa'id Muhammad ar-Ramlawi, Atsar Al-Wasa'il Al-Mustahdatsah Fi Itsbat ArRu'yah Wa Shihhah Ash-Shiyam Fi Al-Figh Al-Islami (Beirut: Dar al-Basya'ir al-Islami, cet. I, 2010).
Menurut bin Baz, persoalan matlak terjadi perbedaan pendapat dikalangan ulama, namun menurutnya ikhtilâf matlak tidak berlaku (lâ yu'tsir), ketika hilal terlihat di negeri mana saja maka wajib atas umat Islam untuk berpuasa, berbuka (hari raya) dan menyembelih kurban. ${ }^{9}$ Pendapat bin Baz ini sedikit bertentangan dengan kenyataan yang dilakukan oleh Kerajaan Arab Saudi, karena dalam praktiknya Arab Saudi hanya mempedomani rukyat lokal (rukyat yang terjadi di teritorial kerajaan).

2.) Berlaku ikhtilâf matlak (yu'tadd ikhtilâf al-mathâli')

Pendapat ini dipedomani oleh Syafi'iyah dan sebagian Hanafiyah. AnNawawi (w. 676 H), seorang ulama terkemuka dalam mazhab Syafi'i mengatakan bahwa tiap-tiap negeri berlaku rukyat masing-masing, jika hilal terlihat di suatu negeri maka rukyat itu tidak berlaku bagi negeri lain yang berjauhan (lâ yatsbut hukmuhu limâ ba'uda). ${ }^{10}$ Dalil dan wajh istidlâl pendapat ini adalah:

a. berdasarkan hadis Kuraib:

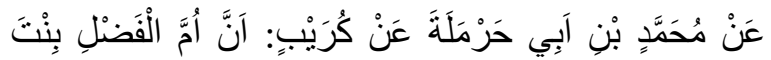

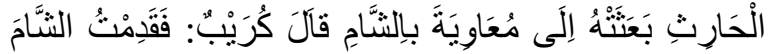

9 Abdul Aziz bin Abdillah bin Abdirrahman bin Baz, Majmu' Fatâwâ Wa Maqâlât Mutanawwi'âh, j. 15 (Riyad: Dar al-Qasim li anNasyr, 1421).

${ }^{10}$ Muhy ad-Dîn bin Syarf an-Nawawî, Kitâb Al Majmû' Syarh Al Muhadzab Li as Syîrazy, j. 6, Tahkik: Muhammad Najib Al Muthi'i (Jeddah: Maktabah al Irsyad). 


\section{AL-MARSHAD: JURNAL ASTRONOMI ISLAM DAN ILMU-ILMU BERKAITAN \\ ISSN 2442-5729 (print) || ISSN 2598-2559 (online) \\ http://jurnal.umsu.ac.id/index.php/almarshad \\ DOI: //doi.org/10.30596/jam.v7i1.6861 | Vol. 7, No. 1Juni 2021}

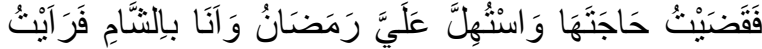

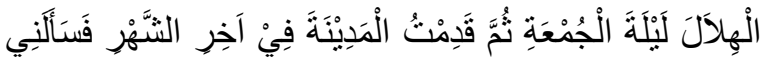

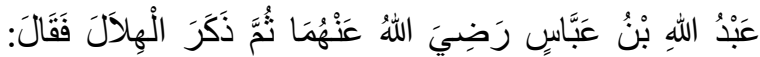

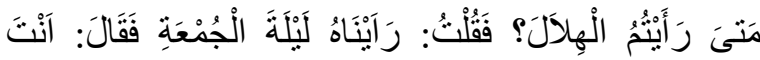

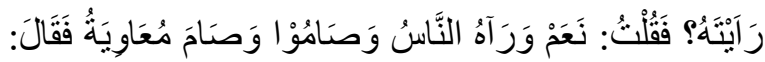

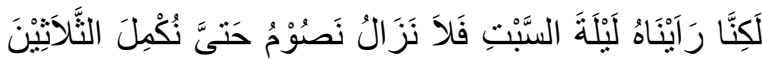

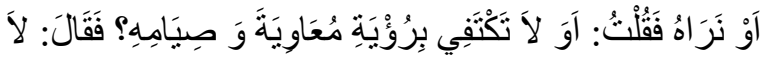

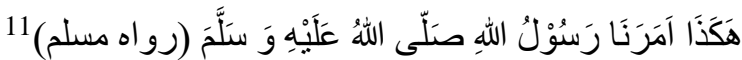

"Dari Muhammad bin Abi Harmalah dari Kuraib, bahwa Umm al-Fadhl binti al-Harits mengutus Kuraib menemui Mu'awiyah di Syam. Kuraib berkata: Aku tiba di Syam. Lalu aku tunaikan keperluan Umm al-Fadhl. Dan terlihatlah hilal bulan Ramadhan olehku, sementara aku masih berada di Syam. Aku melihat hilal pada malam Jum'at. Kemudian aku tiba di Madinah di akhir bulan Ramadhan. Abdullah bin Abbas bertanya kepadaku, dan ia menyebut hilal. Ia berkata: "Kapan kamu melihat hilal?" Aku berkata: "Malam Jum'at." Dia bertanya: "Apakah kamu sendiri melihatnya?" Aku menjawab: "Ya, dan orang-orang juga melihatnya. Mereka berpuasa, demikian juga Mu'awiyah." Dia berkata: "Tetapi kami melihat hilal pada malam Sabtu, maka kami tetap berpuasa sehingga kami sempurnakan 30 hari atau kami melihat hilal". Aku bertanya: "Apakah tidak cukup mengikuti

11 Muslim bin al-Hajjaj, Shahîh Muslim, Tahkik: Syekh Khalil Ma'mun Syiha (Beirut: Dar alMa'rifah, cet. I, 2005). rukyat Mu'awiyah dan puasanya?" Lalu dia menjawab: "Tidak, demikianlah Rasulullah Saw menyuruh kami." (HR. Muslim)

Hadis Kuraib ini secara zahir menunjukkan bahwa tiap-tiap negeri berlaku rukyat masing-masing. Rukyat negeri lain tidak memadai digunakan untuk menetapkan awal puasa dan hari raya, karena Ibn Abbas tidak berpedoman kepada rukyat yang terjadi pada penduduk Syam (Damaskus). Secara tegas Ibn Abbas mengatakan "beginilah kami diperintah oleh Nabi Saw". Sikap Ibn Abbas ini menunjukkan kepatuhan pada ketentuan Nabi Saw.

b. sebab memulai puasa-hari raya adalah bulan (asy-syahr) dan tiap-tiap orang (penduduk) berlaku tuntutan (mukhâthab) masing-masing.

Terjadinya rukyat bagi suatu penduduk (negeri) tidak berlaku bagi penduduk negeri lain karena berbeda matlak. Tiap-tiap penduduk berlaku tuntutan (mukhâthab) masing-masing. Penampakan hilal berbeda antara satu wilayah dengan wilayah lain dengan sebab berbedanya wilayah (ikhtilâf al-aqthâr). Seperti tiba dan berakhirnya waktu salat antara satu wilayah dengan wilayah lain berbeda-beda dengan sebab berbeda wilayah. Tatkala matahari tergelincir atau terbenam di suatu tempat maka kewajiban salat Zuhur atau Magrib 


\section{AL-MARSHAD: JURNAL ASTRONOMI ISLAM DAN ILMU-ILMU BERKAITAN \\ ISSN 2442-5729 (print) || ISSN 2598-2559 (online) \\ http://jurnal.umsu.ac.id/index.php/almarshad \\ DOI: //doi.org/10.30596/jam.v7i1.6861 | Vol. 7, No. 1Juni 2021}

berlaku untuk wilayah itu, yaitu negeri yang berlaku zawal dan gurub. Untuk wilayah lainnya (yang tidak/belum mengalami zawal dan gurub) ketentuan Zuhur atau Magrib belum berlaku.

Lebih lanjut an-Nawawi menyatakan jika terdapat keraguan tentang matlak, maka tidak wajib bagi seseorang yang tidak melihat hilal untuk memulai berpuasa, karena pada dasarnya ketika itu belum datang (masuk) bulan Ramadhan, karena dasar memulai puasa adalah terlihatnya hilal. ${ }^{12}$ Al-Mawardi sebagaimana dinukil anNawawi mendetailkan lagi, jika hilal terlihat disuatu tempat dan tidak terlihat di tempat lain, al-Mawardi memberi tiga pendapat:

Pendapat pertama, bagi wilayah yang tidak melihat hilal tetap wajib memulai berpuasa, karena kewajiban puasa tidak berkaitan dengan perbedaan wilayah, dan pada dasarnya hilal sudah terlihat (matlak global). Pendapat kedua, tidak wajib memulai berpuasa, karena terbit dan tenggelam bulan \& matahari antara satu wilayah dengan wilayah lain berbeda-beda, sebagaimana waktu fajar yang berbeda antara satu tempat dengan tempat yang lain (matlak lokal). Pendapat ketiga, jika dua wilayah itu dalam satu iklim maka wajib berpuasa secara bersama, mengikut rukyat negeri lain yang sudah melihat hilal (matlak wilayatul hukmi). ${ }^{13}$

c. Tidak adanya perintah (dalil) yang menyatakan untuk bertanya atau menunggu kepada wilayah (Negara) lain tatkala hilal tidak terlihat di suatu wilayah (negeri). Ini menandakan bahwa tiap-tiap negeri berlaku hukum rukyat masing-masing (matlak lokal). Hadis Kuraib: Tinjauan Historis-Astronomis

Secara astronomis, kota Syam (sekarang Damaskus) yang terletak di negara Syria berada pada Bujur $36^{\circ} 18^{\prime}$ dan Lintang $33^{\circ} 30^{\prime}$ dan berada pada ketinggian $730 \mathrm{M}$ dari permukaan laut. Sementara kota Madinah berada pada Bujur $39^{\circ} 4^{\prime}$ dan Lintang $24^{\circ} 33^{\prime}$ dan berada pada ketinggian $625 \mathrm{M}$ dari atas permukaan laut. Selisih Bujur keduanya adalah $03^{\circ} 25^{\prime}$ dan selisih Lintang keduanya $08^{\circ} 57^{\prime}$.

Dalam hadis Kuraib di atas disebutkan beberapa keterangan tentang tempat dan tokoh, yaitu Madinah, Syam (Damaskus), Ibn Abbas, Mu'awiyah bin Shafyan dan bulan Ramadhan. Hadis Kuraib sama sekali tidak menyebut kondisi cuaca ketika itu dan verifikasi orang-orang yang melakukan rukyat baik di Syam maupun di Madinah. Hadis Kuraib juga tidak menyebut tahun kejadian atau musim.

Namun untuk tahun terjadinya peristiwa dapat di analisa sebagai berikut, Mu'awiyah mulai naik tahta tahun $41 \mathrm{H}$.

${ }^{12}$ Muhy ad-Dîn bin Syarf an-Nawawî.

${ }^{13}$ Muhy ad-Dîn bin Syarf an-Nawawî. 


\section{AL-MARSHAD: JURNAL ASTRONOMI ISLAM DAN ILMU-ILMU BERKAITAN \\ ISSN 2442-5729 (print) || ISSN 2598-2559 (online) \\ http://jurnal.umsu.ac.id/index.php/almarshad \\ DOI: //doi.org/10.30596/jam.v7i1.6861 | Vol. 7, No. 1Juni 2021}

Mu'awiyah wafat tahun $60 \mathrm{H}$, sementara Ibn Abbas wafat tahun $68 \mathrm{H}$. Dengan demikian Ramadhan dimaksud dalam hadis Kuraib diperkirakan terjadi antara tahun $41 \mathrm{H}$ sampai $59 \mathrm{H}$ (dalam kurun 19 tahun). Hadis Kuraib menjelaskan bahwa Ramadhan di Damaskus dimulai pada hari Jum'at sementara di Madinah pada hari Sabtu.

'Adnan 'Abd al-Mun'im Qadhi dalam karyanya "al-Ahillah Nuzhrah Syumûliyyah wa Dirâsât Falakiyyah" telah melakukan penelitian astronomis hilal di kota Damaskus \& Madinah dari tahun $41 \mathrm{H}$ s.d. tahun $59 \mathrm{H}$. Parameter penelitian Qadhi adalah kelahiran hilal (wiladah al-hilâl), tenggelam matahari \& bulan, sudut ketinggian bulan dari ufuk (zâwiyah irtifâ' al-qamar), sudut pemisah (angular separation, al-infishâl az-zâwy) antara bulan \& matahari setelah terbenam, dan parameter lainnya. Dari penelitian ini ditemukan sebanyak 2 kali hilal muncul pada hari Jum'at yaitu tahun $42 \mathrm{H}$ dan tahun $50 \mathrm{H}$. Sementara hilal yang muncul pada hari Sabtu terjadi sebanyak 4 kali yaitu tahun 44 $\mathrm{H}, 47 \mathrm{H}, 52 \mathrm{H}$, dan $55 \mathrm{H}^{14}$

Secara geografis, kota Madinah berada disebelah timur kota Damaskus (Syam) sehingga peluang terlihatnya hilal di Syam lebih memungkinkan. Dalam peredarannya hilal bergerak dari arah barat menuju arah

14 'Adnan 'Abd al-Mun'im Qadhi, Al-Ahillah Nuzhrah Syumûliyyah Wa Dirâsât Falakiyyah (Kairo: ad-Dar al-Mishriyyah al-Lubnaniyyah, cet. I, 2005). timur, semakin ke barat peluang hilal untuk dapat terlihat lebih besar. Dengan demikian secara astronomis kemunculan hilal di Syam (Damaskus) memungkinkan lebih dulu dari kota Madinah. Hilal (bulan) dalam siklusnya mengelilingi bumi dalam satu bulan menghabiskan waktu 29 hari 12 jam 44 menit 2,8 detik. Saat melintas antara bumi dan matahari, bulan berada pada titik terdekat dengan garis lurus antara titik pusat matahari dan titik pusat bumi, ini disebut ijtimak atau konjungsi yaitu saat bulan berada antara matahari dan bumi. Matahari, yang dalam gerak semunya berjalan mengelilingi bumi akan selalu terkejar oleh bulan sebanyak 12 kali dalam satu tahun.

Ukuran dan Teritorial Matlak

Terdapat perbedaan pendapat dikalangan fukaha dan ulama kontemporer tentang batas ukuran (tahdîd masâfah) berlakunya matlak. Menurut mazhab Syafi'i, ukuran matlak adalah: (1) berdasarkan perbedaan terbit dan tenggelam bulan \& matahari seperti Hijaz, Irak dan Khurasan, (2) berada dalam satu iklim, dan (3) sejauh jarak berlaku qashr salat. ${ }^{15}$ Syekh Wahbah az-Zuhaili menyebutkan, ukuran ikhtilâf matlak tidak kurang dari 24 farsakh. Satu farsakh $=5544$, ukuran ini sama dengan: $5544 \times 24=133,056$ KM. $^{16}$

\footnotetext{
${ }^{15}$ Muhy ad-Dîn bin Syarf an-Nawawî.

${ }^{16}$ Wahbah az Zuhaili.
} 


\section{AL-MARSHAD: JURNAL ASTRONOMI ISLAM DAN ILMU-ILMU BERKAITAN \\ ISSN 2442-5729 (print) || ISSN 2598-2559 (online) \\ http://jurnal.umsu.ac.id/index.php/almarshad \\ DOI: //doi.org/10.30596/jam.v7i1.6861 | Vol. 7, No. 1Juni 2021}

\begin{abstract}
Dalam berbagai seminar internasional tentang matlak, terdapat kecendrungan untuk menerapkan matlak global dalam penentuan awal bulan. Adapun keputusan-keputusan seminar internasional tentang matlak antara lain sebagai berikut:

1. Keputusan Akademi Riset Islam (Majma' al-Buhuts al-Islâmiyyah) tahun 1385/1966 di Mesir
\end{abstract}

Kesimpulan seminar ini meniadakan ikhtilâf matlak (alghâ ikhtilâf al-mathâli'). Rukyat di suatu negeri berlaku bagi negerinegeri lainnya selama bergabung pada sebagian malamnya.

Teks keputusan:

"Muktamar memutuskan bahwasanya tidak berlaku pemisahan matlak meskipun berjauhan iklim (wilayah) selama bergabung pada sebagian malamnya (walau sedikit) pada waktu terjadinya rukyat. Pemisahan matlak akan berlaku apabila tidak bergabung pada sebagian malamnya". ${ }^{17}$

2. Keputusan Lembaga Muktamar Islam (Munazhzhamah al-Mu'tamar al-Islâmî) tahun 1406/1986

Muktamar ini memutuskan tidak berlakunya ikhtilâf matlak. Apabila rukyat terjadi di suatu negeri maka berlaku bagi negeri-negeri lainnya.

Teks keputusan:

"Pertama: apabila telah terbukti terjadi rukyat di suatu negeri maka wajib atas kaum muslimin mempedomaninya. Pemisahan matlak tidak berlaku karena umumnya khitâb (tuntutan) perintah puasa dan hari raya". ${ }^{18}$

3. Keputusan Simposium Hilal dan WaktuWaktu Astronomi (Nadwah al-Ahillah wa al-Mawâqît al-Falakiyyah) tahun 1409/1989 di Kuwait

Simposium ini berlangsung sejak 21 s.d. 23 Rajab 1409 H bertepatan 25 s.d. 27 Maret 1989 M. Negara-negara yang bergabung dalam simposium ini antara lain: Yordania, Uni Emirat Arab, Aljazair, Arab Saudi, Sudan, Aman, Palestina, Qatar, Kuwait, Mesir, Maroko dan Yaman. Simposium memutuskan tidak berlakunya ikhtilâf matlak.

Teks keputusan:

"Apabila terbukti di satu negeri hilal telah terlihat maka wajib kepada umat Islam mempedomaninya. Pemisahan matlak tidak berlaku karena keumuman khitab (tuntutan) perintah puasa dan hari raya". ${ }^{19}$

\section{Keputusan Akademi Ahli Fikih (Majma'} Fuqahâ' asy-Syarî'ah) Amerika Utara tahun 1425 H/2004 M

Keputusan akademi ini sama seperti keputusan Akademi Riset Islam (Majma' al-Buhûts al-Islâmiyyah) tahun

${ }^{17}$ Muhammad Sa'id Muhammad ar-Ramlawi.

${ }^{18}$ Muhammad Sa'id Muhammad ar-Ramlawi.
${ }^{19}$ Muhammad Sa'id Muhammad ar-Ramlawi. 


\section{AL-MARSHAD: JURNAL ASTRONOMI ISLAM DAN ILMU-ILMU BERKAITAN \\ ISSN 2442-5729 (print) || ISSN 2598-2559 (online) \\ http://jurnal.umsu.ac.id/index.php/almarshad \\ DOI: //doi.org/10.30596/jam.v7i1.6861 | Vol. 7, No. 1Juni 2021}

1385/1966 di Mesir yaitu tidak (Makah Times) dan sesuai dengan memberlakukan ikhtilâf matlak. ${ }^{20}$

5. Keputusan Dewan Fatwa dan Penelitian Eropa (al-Majlis al-Urubbî li al-Iftâ' wa alBuhûts) tahun $1426 \mathrm{H} / 2005 \mathrm{M}$

Dewan ini memutuskan sama seperti keputusan Akademi Ahli Fikih Amerika Utara tahun 1425/2004 yaitu tidak memberlakukan ikhtilâf matlak. $^{21}$

6. Keputusan Seminar bersama tentang Kalender, Matlak, Waktu Salat Isya' \& Subuh antara Kerajaan Arab Saudi dan Republik Arab Mesir tahun 2007 M di Mesir

Seminar ini berlangsung di gedung observatorium Astronomi Helwan-Mesir pada tanggal 30 Oktober 2007 M. Selain membahas matlak, seminar ini juga membahas tentang Kalender, waktu Salat Isya' dan Subuh. Rekomendasi dalam seminar ini adalah menggunakan matlak Mekah dalam menentukan awan bulan, dengan catatan di kota mulia Mekah telah terjadi ijtimak (konjungsi) dan pada saat itu posisi matahari lebih dahulu terbenam dari bulan.

Teks keputusan:

"Dalam seminar tersebut disepakati titik temu dan menjadi rekomendasi seminar, antara lain: (1) Kalender Hijriyah disusun berdasarkan waktu yang berlaku di Makkah

${ }^{20}$ Muhammad Sa'id Muhammad ar-Ramlawi.

${ }^{21}$ Muhammad Sa'id Muhammad ar-Ramlawi. persyaratan berikut ini: (a) Menggunakan koordinat Mekah sebagai dasar penanggalan, (b) Bulan terbenam setelah Matahari terbenam di kota Makkah al-Mukarramah, dan (c) Telah terjadi konjungsi (iqtirân) sebelum terbenamnya Matahari di kota Makkah al-Mukarramah. Apabila prasyarat di atas telah terpenuhi, maka keesokan harinya bisa dihitung sebagai hari pertama bulan baru dalam kalender hijriyah atau kalender bulan".

Problem dan Prospek Penerapan Matlak

Perbedaan matlak adalah sunnatullâh yang tidak dapat diingkari. Kenyataan bahwa perbedaan ini membawa perdebatan dikalangan ulama klasik dan ulama kontemporer. Perdebatan itu bermuara pada dua pendapat, yaitu: ittihâd matlak dan ikhtilâf matlak. Masing-masing dari pendapat ini memiliki sisi kekurangan dan kelebihan. Pendapat yang menyatakan berlakunya pemisahan matlak (matlak lokal) oleh kalangan yang mendukung penyeragaman (matlak global) di bantah dengan dalil-dalil dan logika sebagai berikut: a. Hadis Kuraib, yang menyatakan berlakunya ikhtilâf matlak, tidak dapat dijadikan dalil (lâ dalîla fîhi). Karena pernyataan kesaksian (bahwa hilal terlihat di Syam) tidak dikonfirmasi dengan kesaksian lainnya, dan juga tidak 


\section{AL-MARSHAD: JURNAL ASTRONOMI ISLAM DAN ILMU-ILMU BERKAITAN \\ ISSN 2442-5729 (print) || ISSN 2598-2559 (online) \\ http://jurnal.umsu.ac.id/index.php/almarshad \\ DOI: //doi.org/10.30596/jam.v7i1.6861 | Vol. 7, No. 1Juni 2021}

ditetapkan oleh pemerintah (al-hâkim) sehingga tidak cukup kuat.

b. Laporan terlihatnya hilal tidak berdasarkan kalimat kesaksian (lafzh asysyahadah), bahkan kesaksian tersebut hanya satu orang. Kesaksian satu orang tidak dapat dijadikan pedoman bagi seorang qâdhî. Imam asy-Syaukani (w. 1250 H) dalam 'Nail al-Authâr' menganggap hadis Kuraib sebagai hujjah marf $\hat{u}$ ' dari riwayat Ibn Abbas. Hadis ini muncul sama sekali bukan melalui ijtihad Ibn Abbas, karena ketika dikonfirmasi tentang rukyat di Syam Ibn Abbas hanya mengatakan 'hakadzâa amaranâ rasulullâh' (beginilah kita diperintah oleh Nabi Saw), Ibn Abbas dan penduduk Madinah tetap berpuasa meski hilal sudah terlihat di Syam (Damaskus). Ibn Abbas juga tidak menukil redaksi Nabi Saw tentang rukyat atau istikmâl dalam menjawab pertanyaan dari Kuraib, Ibn Abbas hanya memberi penjelasan yang bersifat umum (mujmal) yang menyatakan penduduk Madinah tidak menerima rukyat dari Syam. ${ }^{22}$ AsySyaukani juga menyatakan hadis Kuraib

${ }^{22}$ Muhammad bin 'Alî bin Muhammad asySyaukânî, Nail Al-Authâr Syarh Muntaqâ Al Akhbâr Min Ahâdîts Sayyidil Akhyâr, j. 4, Tahkik: Dr. Muhammad Muhammad Tamir (Kairo: Dar Ibn alHaitsam, 2004). ini tidak menunjukkan secara jelas tentang ikhtilâf matlak'. ${ }^{23}$

c. hadits A'rabi:

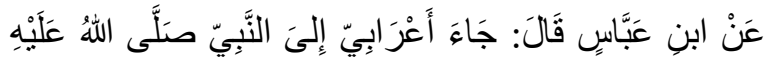

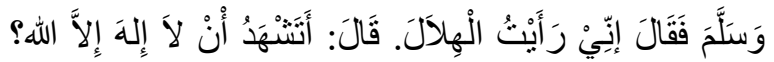

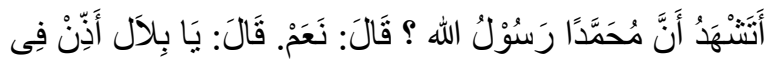
النَّاسِ أَنْ يَصُوْمُوْا غَدًا [خرجه النسائي وأبو داود وابن لِّن ماجه و الدارمي و الترمذي و اللفظ لهـ]

"Dari Ibn Abbas, ia berkata: "Telah datang seorang a'rabi (arab badui) kepada Nabi Saw., mengatakan: 'aku telah melihat hilal', Nabi Saw bertanya, apakah engkau bersaksi bahwa tidak ada Tuhan selain Allah? Apakah engkau bersaksi bahwa Muhammad Saw adalah utusan Allah? A'rabi menjawab: ya, lantas Nabi Saw berkata, ya Bilal umumkanlah kepada manusia dan hendaklah besok mereka berpuasa”. (HR. Nasa'i, Abu Dawud, Ibn Majah, ad-Darimi, dan atTirmidzi)

Hadis ini dipandang sebagai dalil tidak adanya perbedaan matlak, meskipun masih 'debatable'. Dalam hadis ini, ketika seorang A'rabi mengkonfirmasi terlihatnya hilal, Nabi Saw tidak mengatakan, "kami tidak melihat hilal disini', Nabi Saw justru bertanya tentang keimananya dan memerintahkan Bilal untuk mengumumkan Syaukânî.

${ }^{23}$ Muhammad bin 'Alî bin Muhammad asy-

${ }^{24}$ Muhy ad-Dîn bin Syarf an-Nawawî. 


\section{AL-MARSHAD: JURNAL ASTRONOMI ISLAM DAN ILMU-ILMU BERKAITAN ISSN 2442-5729 (print) || ISSN 2598-2559 (online) \\ http://jurnal.umsu.ac.id/index.php/almarshad \\ DOI: //doi.org/10.30596/jam.v7i1.6861 | Vol. 7, No. 1Juni 2021}

kepada kaum muslimin. Artinya, Nabi Saw menerima kesaksian seorang A'rabi. Tidak diketahui secara persis jarak (masâfah) tempat tinggal antara Nabi Saw dan A'rabi, namun biasanya A'rabi tinggal di daerah pegunungan yang jauh dari kota Madinah sehingga boleh jadi ada perberbedaan matlak. Sebagaimana hadis juga tidak menyebutkan dimana A'rabi melihat hilal, dan kapan terjadinya dialog antara Nabi Saw dan A'rabi.

Memposisikan hadis A'rabi ini sebagai hujah tidak adanya perbedaan matlak lebih utama dari hadis Kuraib karena adanya keterlibatan Nabi Saw secara langsung, dan Nabi Saw memutus perkara seketika itu pula. Sementara dalam hadis Kuraib tidak ada keterlibatan Nabi Saw secara langsung. Pendapat ini juga diperkuat dengan alasan bahwa dengan penyeragaman matlak (ittihâd al-mathâli') berpotensi menyatukan umat Islam seluruh dunia.

Dalam hal ini, menurut penulis, matlak lokal wilayatul hukmi dipandang lebih tepat untuk diterapkan. Dengan alasan sebagai berikut:

1. Pernyataan tegas Ibn Abbas. Ibn Abbas adalah sahabat yang dekat dengan Rasulullah Saw sehingga perkataan dan perbuatannya laksana bintang yang patut diikuti.
2. Tidak bertentangan dengan ilmu pengetahuan. Menerapkan ittihâd matlak (matlak global) akan bertentangan dengan ilmu pengetahuan modern. Hilal yang terlihat di suatu negeri belum tentu terlihat di negeri lain, bahkan di negeri lain sangat mungkin belum terjadi ijtimak (konjungsi) atau hilal belum mencapai titik finis peredarannya.

3. Menerapkan matlak global menimbulkan kesulitan secara teknis, karena perukyat di satu negeri harus senantiasa saling berkoordinasi antara satu negeri dengan negeri-negeri lainnya di penjuru bumi. Praktek seperti ini juga akan menghilangkan semangat observasi (rukyat) di suatu negeri karena sudah memadakan dengan rukyat negeri lain. Secara astronomis kemunculan hilal dapat diprediksi secara teliti sehingga negeri yang sudah dipastikan tidak dapat melihat hilal tidak lagi melakukan observasi. Padahal observasi (diantaranya rukyat) adalah salah satu identitas peradaban Islam yang terbentuk zaman berzaman.

4. Matlak global sama sekali tidak menjamin persatuan dalam memulai puasa dan hari raya karena secara astronomis hal itu sulit diterapkan bahkan mustahil terwujud. Wallâhu a'lam

Namun demikian, dalam praktik modern, konsep matlak lokal menyisakan 


\section{AL-MARSHAD: JURNAL ASTRONOMI ISLAM DAN ILMU-ILMU BERKAITAN \\ ISSN 2442-5729 (print) || ISSN 2598-2559 (online) \\ http://jurnal.umsu.ac.id/index.php/almarshad \\ DOI: //doi.org/10.30596/jam.v7i1.6861 | Vol. 7, No. 1Juni 2021}

banyak problem. Problem-problem dimaksud adalah:

1. Jika matlak yang diberlakukan adalah rukyat (matlak) lokal secara konsisten maka sangat memungkinkan terjadi dua matlak atau dua hari raya dalam satu negara kesatuan. Contoh konkritnya adalah negara Indonesia yang terbentang luas dari barat sampai timur. Merupakan fakta, fenomena hilal yang membelah wilayah kesatuan NKRI sudah terjadi berkali-kali, baik dengan menganut konsep rukyat (matlak) versi NU, imkanur rukyat Pemerintah, atau konsep wujudul hilal Muhammadiyah .

2. Jika konsisten merujuk pada pendapat fukaha tentang berlakunya ikhtilâf matlak (mazhab Syafi'i dan sebagian Hanafiyah) maka dalam konteks modern menimbulkan persoalan yaitu pada penerimaan dan penggunaan sepenuhnya praktik rukyat. Padahal di zaman modern saat ini dominasi hisab semakin menguat dan semakin mendapat apresiasi. Betapapun sebagian ulama Syafi'iyah seperti as-Subki, Ibn Suraij, Ibn Qutaibah dan lainnya mendukung penggunaan hisab, namun pendapat mereka ini hanya pendapat minoritas dan pribadi dimasanya dan tidak merepresentasikan mazhab. Bahkan, sejauh pengamatan penulis, hisab yang diakomodir oleh segelintir ulama Syafi'iyah ini hanya sebatas "li nafyi" (untuk memverifikasi laporan rukyat) bukan "li itsbat" (untuk menetapkan masuknya awal bulan). Wallâhu a'lam

Karena itu matlak lokal yang ideal adalah "matlak lokal wilayatul hukmi modern". Konsep matlak ini mengapresiasi pendapat ketiga al-Mawardi dan ulama lainnya. Matlak lokal wilayatul hukmi modern adalah batas geografis-astronomis keberlakuan terlihatnya hilal (baik dengan rukyat tepat atau dengan hisab akurat) dalam satu negara kesatuan yang ditetapkan oleh negara. Perlunya ditetapkan oleh negara agar keputusan tersebut berlaku mengikat dan patuh bagi semua warga negara. Sementara itu "modern" agar penetapan terlihatnya hilal dapat menggunakan salah satu metode (hisab atau rukyat) atau kombinasi antara keduanya secara akurat dan ilmiah dan tidak bertentangan dengan ilmu pengetahuan modern. Namun tentunya konsep ini masih berhadapan dengan konsep Kalender Islam Unifikasi oleh Jamal ad-Din ar-Raziq yang belakangan mulai diperbincangkan. Konsep kalender ini berobsesi hendak menyatukan kalender Islam (khususnya puasa dan hari raya) di seluruh dunia secara bersama yaitu dengan menjadikan 'matlak universal.

Konsep ini sejatinya dalam praktiknya akan mengakomodir hisab secara 


\section{AL-MARSHAD: JURNAL ASTRONOMI ISLAM DAN ILMU-ILMU BERKAITAN \\ ISSN 2442-5729 (print) || ISSN 2598-2559 (online) \\ http://jurnal.umsu.ac.id/index.php/almarshad \\ DOI: //doi.org/10.30596/jam.v7i1.6861 | Vol. 7, No. 1Juni 2021}

lebih dominan dibanding rukyat. Karena mau tidak mau konsep ini harus mengakomodir hisab secara signifikan, posisi hisab tidak lagi "li nafyi" tapi "li nafyi" dan "li itsbat" secara sekaligus. Meski pada tataran teorinya memberi ruang terhadap rukyat (ini tetap perlu demi menghormati literal hadis dan merutini tradisi observasi) namun penentuan final tetap pada hisab. Sikap tegas terhadap penggunaan hisab ini didasari pada kenyataan bahwa kita hidup di zaman dimana ilmu pengetauan sangat berkembang pesat. Kenyataan lagi, hilal yang menjadi obyek disini merupakan benda angkasa ciptaan Allah Swt yang dapat dikaji melalui ilmu pengetahuan modern, dalam hal ini ilmu falak (astronomi).

Pengakomodiran hisab ini tidak mengindikasikan bahwa kita tidak lagi mengamalkan rukyat atau tidak mematuhi perintah Nabi Saw. Rukyat tetap diterapkan, namun pengakomodirannya tidak seperti yang diterapkan oleh hadis-hadis Nabi Saw dan para fukaha, karena dalam konteks modern banyak faktor astronomis yang harus dipertimbangkan dan diperhatikan dalam aktifitas rukyat. Dalam konteks modern rukyat dapat dipahami secara lebih general yaitu rukyat dengan ilmu. Sejatinya, latar sosio religius-intelektual (meminjam istilah Azyumardi Azra) antara zaman fukaha dengan zaman modern telah berbeda sehingga penafsiran dan ijtihadnya berbeda pula.

Perlu dicatat, dalam penjabarannya konsep ini tetap mengakomodir rukyat bil fi'li dengan tetap menggunakan parameter visibilitas hilal. Sehingga dengan demikian tetap dapat diobservasi di lapangan oleh pihak yang berkeinginan dan berkepentingan. Sesungguhnya dengan menggunakan hisab saja sudah memadai, namun rukyat tetap harus diakomodir secara zahir karena sejatinya dua hal ini tidak dapat di pisahkan. Secara historis hisab lahir dari pengamatan (observasi empirik) berulangulang yang pada akhirnya melahirkan satu konsep ilmu, yaitu hisab. Dalam diskursus modern, muncul sebuah adagium yang menyatakan "rukyat yang tepat akan bersesuaian dengan hisab akurat" (ar-ru'yah ash-shahîhah muwâfiq li al-hisâb ad-daqîq). Matlak Indonesia: Antara Teks dan Konteks Wilayah Indonesia yang terbentang luas dari Barat sampai Timur pada kenyataannya menimbulkan problema dalam penentuan awal puasa dan hari raya. Di Indonesia berlaku istilah matlak hukmi atau matlak wilayatul hukmi, dengan pengertian apabila hilal telah terlihat (baik dengan rukyat atau dengan hisab) di satu wilayah NKRI, maka berlaku bagi seluruh wilayah kesatuan Indonesia tanpa terkecuali. 


\section{AL-MARSHAD: JURNAL ASTRONOMI ISLAM DAN ILMU-ILMU BERKAITAN \\ ISSN 2442-5729 (print) || ISSN 2598-2559 (online) \\ http://jurnal.umsu.ac.id/index.php/almarshad \\ DOI: //doi.org/10.30596/jam.v7i1.6861 | Vol. 7, No. 1Juni 2021}

\section{Pemerintah}

menggunakan konsep matlak wilayatul hukmi dengan parameter hisab imkanur rukyat dengan visibilitas dua derajat. Penetapan ini dilakukan berdasarkan metode rukyat dan hisab yang berlaku secara nasional. Dalam penjabarannya konsep Pemerintah ini mengakomodir ayat-ayat berkaitan dan hadis-hadis rukyat secara bersamaan, dan ditambah dalil (kaidah) fikih yang menyatakan bahwa keputusan pemerintah berlaku mengikat (wajib dipatuhi) dan menghilangkan silang pendapat. Lihat: Keputusan Fatwa Majelis Ulama Indonesia Nomor 2 Tahun 2004 tentang Penetapan Awal Ramadhan, Syawal, dan Dzulhijah. Pada realitanya konsep ini memiliki kelemahan, antara lain:

a. Pada realitanya aplikasi matlak dengan parameter imkanur rukyat dua derajat banyak mendapat penolakan dari para praktisi hisab dan ilmuwan.

b. Memungkinkan di satu wilayah NKRI (umumnya wilayah timur) hilal belum mencapai ambang batas seperti yang disepakati (yaitu dua derajat). Betapapun dapat teratasi dengan alasan wilayatul hukmi, namun masih bertentangan dengan ilmu pengetahuan. Artinya konsep pemerintah ini bukan konsep yang dimaksud dalam makalah ini.

\section{Sementara}

menggunakan matlak wilayatul hukmi dengan parameter hisab wujudul hilal. ${ }^{25}$ Konsep matlak Muhammadiyah ini juga memiliki kelemahan seperti halnya konsep matlak pemerintah. Dalam banyak kasus, Muhammadiyah pernah mengeluarkan keputusan yang bertentangan dengan ilmu pengetahuan dan bahkan 'terkesan' tidak konsisten dengan metode (konsep matlak) yang dipedomani. Contoh konkritnya adalah ketika hilal membelah wilayah NKRI yang memaksa Indonesia berada pada dua matlak, kasus pertama terjadi pada tahun 1381/1962. Cukup sulit mencari dalil syar'i dan logika konsep ini ketika dua matlak terjadi dalam lingkup NKRI dengan menggunakan konsep wujudul hilal. Padahal motivasi utama konsep wujudul hilal adalah apresiasi terhadap ilmu pengetahuan. Wallâhu a'lam

Sementara itu NU menggunakan matlak wilayatul hukmi dengan parameter rukyat bil fi'li. ${ }^{26}$ Konsep ini dalam prakteknya juga memiliki kelemahan seperti halnya pemerintah dan Muhammadiyah. Karena dalam aplikasi matlaknya NU tidak memiliki rumusan (batasan) yang jelas dan ilmiah, aspek ta'abbudî (kepatuhan literal)

${ }^{25}$ Majelis Tarjih dan Tajdid Pimpinan Pusat Muhammadiyah, Panduan Hisab Muhammadiyah (Yogyakarta: Suara Muhammadiyah, cet. II, 2009).

${ }^{26}$ Ghazalie Masroerie, Penentuan Awal Bulan Qamariyah Perspektif Nahdlatul Ulama (Workshop Nasional Metodologi Penetapan Awal Bulan Qamariyah Model Muhammadiyah, 2002). 


\section{AL-MARSHAD: JURNAL ASTRONOMI ISLAM DAN ILMU-ILMU BERKAITAN \\ ISSN 2442-5729 (print) || ISSN 2598-2559 (online) \\ http://jurnal.umsu.ac.id/index.php/almarshad \\ DOI: //doi.org/10.30596/jam.v7i1.6861 | Vol. 7, No. 1Juni 2021}

lebih dominan dibanding aspek ta'aqqulî (penalaran ilmiah). Maksudnya, konsep ini tidak dikombinasikan dengan sains modern secara aktif (meskipun dalam teorinya sains tetap digunakan), dalam faktanya sering terjadi kesimpang siuran keputusan. Kasus yang paling mencolok adalah Idul Fitri tahun 1418/1998. Menempatkan sains (dalam hal ini hisab) pada posisi pelengkap atau pembantu, dalam konteks modern tidaklah cukup.

\section{Kesimpulan}

Dari pemaparan diatas, dapat dikemukakan beberapa kesimpulan sebagai berikut:

1. Matlak adalah batas geografis keberlakuan rukyat yang menyebabkan adanya matlak ikhtilâf (matlak lokal) dan matlak ittihâd (matlak global). Istilah matlak muncul setelah masa Nabi Saw atas perbedaan penafsiran terhadap hadis Kuraib.

2. Matlak ikhtilâf menyatakan apabila hilal terlihat (baik dengan hisab atau dengan rukyat) di satu wilayah tertentu hanya berlaku bagi satu kawasan tertentu saja, sementara matlak ittihâd berlaku menyeluruh.

3. Terdapat dua aliran matlak dikalangan fukaha. Pertama: tidak berlaku ikhtilâf matlak, yaitu pendapat Hanafiyah,
Malikiyah, sebagian Syafi'iyah dan Hanabilah. Kedua: berlaku ikhtilâf matlak, yaitu pendapat Syafi'iyah dan sebagian Hanafiyah.

4. Di Indonesia terdapat tiga model penerapan matlak, yaitu matlak versi NU, matlak versi Pemerintah dan matlak versi Muhammadiyah, yang masing-masing memiliki perbedaan, kelebihan dan kekurangan.

5. Dalam konteks modern, 'matlak lokal wilayatul hukmi modern' adalah konsep matlak yang paling ideal untuk diterapkan dalam satu wilayah negara kesatuan, Indonesia misalnya. Namun konsep ini masih sebatas wacana dan membutuhkan rumusan dan diskusi lebih lanjut.

\section{Daftar Pustaka}

'Abd ar-Rahmân al-Jazîrî, Kitâb Al-Fiqh 'Alâ Al-Madzâhib Al-Arba'Ah (Kairo: Mu'assasah al-Mukhtâr, cet. I, 2001)

'Adnan 'Abd al-Mun'im Qadhi, Al-Ahillah Nuzhrah Syumûliyyah Wa Dirâsât Falakiyyah (Kairo: ad-Dar alMishriyyah al-Lubnaniyyah, cet. I, 2005)

Abdul Aziz bin Abdillah bin Abdirrahman bin Baz, Majmu' Fatâwâ Wa Maqâlât Mutanawwi'âh, j. 15 (Riyad: Dar alQasim li an-Nasyr, 1421)

Ahmad bin Idris al-Qarafi, Adz-Dzakhirah, $j$. 
2, Tahkik: Al-Ustadz Sai'd Al-A'rab (Beirut: Dar al-Gharb al-Islami, cet. I, 1994)

Ghazalie Masroerie, Penentuan Awal Bulan Qamariyah Perspektif Nahdlatul Ulama (Workshop Nasional Metodologi Penetapan Awal Bulan Qamariyah Model Muhammadiyah, 2002)

Majelis Tarjih dan Tajdid Pimpinan Pusat Muhammadiyah, Panduan Hisab Muhammadiyah (Yogyakarta: Suara

Muhammadiyah, cet. II, 2009)

Muhammad bin 'Alî bin Muhammad asySyaukânî, Nail Al-Authâr Syarh Muntaqâ Al Akhbâr Min Ahâdîts Sayyidil Akhyâr, j. 4, Tahkik: Dr. Muhammad Muhammad Tamir (Kairo:

Dar Ibn al-Haitsam, 2004)

Muhammad Sa'id Muhammad ar-Ramlawi, Atsar Al-Wasa'il Al-Mustahdatsah Fi Itsbat Ar-Ru'yah Wa Shihhah AshShiyam Fi Al-Fiqh Al-Islami (Beirut:

Dar al-Basya'ir al-Islami, cet. I, 2010)

Muhy ad-Dîn bin Syarf an-Nawawî, Kitâb Al

Majmû' Syarh Al Muhadzab Li as Syîrazy, j. 6, Tahkik: Muhammad Najib Al Muthi'i (Jeddah: Maktabah al Irsyad) Muslim bin al-Hajjaj, Shahîh Muslim, Tahkik: Syekh Khalil Ma'mun Syiha

(Beirut: Dar al-Ma'rifah, cet. I, 2005) Susiknan Azhari, Ensiklopedi Hisab Rukyat (Yogyakarta: Pustaka Pelajar, 2005)
- Ilmu Falak Perjumpaan Khazanah Islam Dan Sains Modern (Yogyakarta: Suara Muhammadiyah, cet. II, 2007) Wahbah az Zuhaili, Al-Fiqh Al-Islâmî Wa Adillatuh (Beirut: Dar al Fikr)

Zain ad-Din Muhammad bin Abi Bakr arRazi, Mukhtar Ash-Shihhah (Kairo: Dar as-Salam, cet. I, 2007) 